\title{
4
}

\section{Flaubert's Projects: Pure Art and Carnivalization}

"Not enough forms ....," said Flaubert. How is he to be understood? Does he wish to celebrate the other of form? The "too many things" which exceed and resist form? In praise of Dionysus? One is certain that this is not so. Flaubert, on the contrary, is sighing, "Alas! not enough forms." A religion of the work as form. . . Nietzsche was not fooled: "Flaubert, a new edition of Pascal, but as an artist with the instinctive belief at heart: 'Flaubert est toujours haïssable, l'homme n'est rien, l'oeuvre est tout."”

Jacques Derrida, Writing and Difference

Even in quarters where certainty is notoriously elusive, the conviction that Flaubert's project in writing was a formalistic quest for pure art has by now unseated earlier views of him as a realist or as a frustrated romantic. The entry for Flaubert in the Petit Larousse is an epitome of these earlier views:

Prosateur soucieux de la perfection du style, il veut donner dans ses romans une image objective de la réalité mais garde quelques traits de l'imagination romantique.

(Prose-writer concerned with the perfection of style, he wants to give in his novels an objective image of reality, but keeps some traits of the romantic imagination.)

The deficiencies of this overly pear-shaped conception of Flaubert should be evident, for they reduce him in louis-philippard fashion to an exemplar of the juste milieu in art. But it is 
still conceivable that views stressing his quest for pure art fail to account adequately for the manner in which realism and romanticism are pertinent reference points in his work.

The understanding of Flaubert in terms of a formalist aesthetics nonetheless has a long and impressive lineage. Nietzsche condemned the nihilism implicit in Flaubert's asceticism and displaced Christianity, but Baudelaire sympathetically saw the true gageure in Flaubert's work as the attempt to create beauty from the most rebarbative materials. Henry James, with changing emphases, stressed the importance of Flaubert's dedication to l'art pour l'art and looked to him as "the novelist's novelist." Percy Lubbock, in his Craft of Fiction, codified James's more flexible principles and took Madame Bovary as a test case which he, plausibly but mistakenly, read as exhibiting the role of characters' consciousnesses as the unifying vehicle of narration. And André Gide took Flaubert's letters as a writer's bible whose value surpassed that of the novels themselves. Recently, of course, the image of Flaubert as the apostle of art has received a trenchant and critical formulation in Sartre's Idiot where the thesis is expanded to herculean proportions and developed with an intricacy attesting to the allure of the task and to Sartre's investment in it. Indeed it is significant that, despite differences in evaluative reactions, figures spanning the theoretical spectrum from Marxism to "high modernism" and beyond have in general agreed upon the understanding of Flaubert as the Christ of Art expounding a doctrine of secular redemption in the form of an ivory-tower, elitist escape from the modern crisis.

Much in Flaubert's letters justifies this image of him. But it is misleading to extract from the Correspondance the most lapidary formulations of the ideal of pure art, to identify them as the project of Flaubert, and to read the novels as the straightforward embodiment of this project. For this approach ignores at least two problems: the way the ideal of pure art is itself the object of multiple and at times contradictory "investments" in the letters; and the difficulty in relating a complex, often divided project to the actual functioning of a novel. In the light of these two related problems, let us inquire into the way Flaubert discusses art and its contexts in his letters, examine Sartre's 
interpretation, and raise the question of its adequacy with reference both to Flaubert's "projects" and to the reading or interpretation of Madame Bovary.

Flaubert offered a critique of bourgeois culture which blended imperceptibly into an indictment of humanity and the human condition in general. It was often difficult to distinguish between what was sociocultural and what was universal in his indictment. The bourgeoisie was not a class. It was a condition - the condition of those who thought basely and stupidly. In Flaubert's statements of this conception may be found both an inability to distinguish particular or class conditions from rash generalizations about la condition humaine and an ability to see how certain traits of embourgeoisement might reach further and further down the social scale in modern life. Modern times was the scene of "avachissement universel" (October 5, 1871).

Mediocrity is creeping in everywhere; even stones are becoming stupid [bêtes], and highways too are stupefying [stupides]. Perish though we may (and perish we shall in any case), we must employ every means to stem the flood of excrement [merde] invading us. Let us take flight in the ideal, since we no longer have the means to dwell in marble halls and don purple gowns, have humming-bird feather divans, swansdown carpets, ebony armchairs, tortoise shell floors, solid gold candelabra, or lamps carved in emerald. And so let us blast out [guelons] against gloves made of shoddy, against of fice chairs, against mackintosh, against economical stoves, against imitation luxury, against imitation pride. Industrialism has developed to ugly and gigantic proportions. How many good people who a century ago could have lived without Beaux Arts now cannot do without mini-statues, mini-music, and miniliterature! Take a simple case-the ominous proliferation of bad drawings by lithography. . . . We are all fakes and charlatans. Pretense, affectation, humbug everywhere. Crinoline has falsified buttocks. Our century is a century of whores, and so far what is least prostituted is the prostitute. [January 29, 1854 ]

This all-too-familiar indictment of industrialism, mass consumption, and the "age of mechanical reproduction" begins 
with an evocation of vanishing artificial splendor only to end paradoxically with a nostalgia for unadorned "authenticity." The hypocritical generalization of prostitution makes prostitution itself the one honest phenomenon of the age insofar as it called itself by its proper name. ${ }^{1}$

From a perspective very much attuned to that of Flaubert and in an analysis which Flaubert immediately recognized as the only one to grasp his meaning, Baudelaire summarized the sense of context motivating Flaubert in the composition of Madame Bovary:

For many years, the interest which the public is willing to devote to matters of the spirit has considerably diminished and the allotment of its available enthusiasm has steadily decreased. The last years of Louis-Philippe's reign saw the final outbursts of a spirit still willing to be stimulated by the display of imaginative powers; the new novelist, however, is confronted with a completely worn-out public or, worse even, a stupefied and greedy audience, whose only hatred is for fiction, and only love for material possessions. ${ }^{2}$

In this context where, since the death of Balzac, curiosity about the novel had been "dormant," the challenge facing Flaubert was great. For Baudelaire, Flaubert met it by "resolv[ing] to be vulgar . . . bewar[ing] above all of giving away [his] true feelings and of speaking in [his] own name." Rather Flaubert

1. In this light, the enigmatic ending of The Sentimental Education appears less as an evocation of lost innocence than as a rectification of names: in an age of generalized prostitution, the one proper and authentic emotion is expressed by the laughter of prostitutes at the inappropriately romantic gesture of a young man who brings them flowers. In contradistinction to other characters, the prostitutes at least recognize themselves as prostitutes. Their sincere reaction and the genuine confusion it causes in the young protagonist are perhaps the only honest experiences to be found in the novel-in this sense the best thing that happened to Frédéric and Deslauriers: "ce que nous avons eu de meilleur," as they repeat in sequence. For a somewhat different view, as well as for an insightful discussion of Flaubert's works in general, see Victor Brombert, The Novels of Flaubert (Princeton: Princeton University Press, 1966), especially chapter 4 .

2. "Madame Bovary, by Gustave Flaubert," in Paul de Man, ed., Madame Bovary (New York: Norton, 1965), 338. Baudelaire's article first appeared in L'Artiste on October 18, 1857. 
took the "vague and overflexible term" of realism and filled it with "a nervous, picturesque, subtle and precise style" applied to "a banal canvas." He turned to the provinces, "the breeding ground of stupidity . . . inhabited by the most intolerant imbeciles," and he took "the tritest theme of all, worn out by repetition, by being played over and over again like a tired barrel organ"-adultery. Madame Bovary was born of "the impossible task, the true gageure, the wager which all works of art must be," for it fashioned beauty out of the most inhospitable and vulgar materials. Thus Flaubert's alchemical feat was to transform basely inartistic subject matter into a superlative work of art. $^{3}$

That Flaubert himself found his bourgeois subject alien to the higher purposes of art is a leitmotif of his letters:

I hate bourgeois poetry, domestic art, although I engage in it. But this is the last time. At bottom it disgusts me. This book, composed of calculations and of stylistic ruses, is not of my blood. I do not carry it in my entrails.. I feel it is an entirely willed and factitious thing. This will perhaps be a tour de force that certain people (a very small number indeed!) will admire, and others will find in it some truth of detail and observation. But air! Air! The grand turns of phrase, the large and full periods rolling like rivers, the multiplicity of metaphors, the great bursts of style-all that I love will not be there. At best I shall emerge from it better able to write something good later on. [May 21-22, 1853]

Flaubert's self-doubt went so far as to risk falsifying the very dictum that absolute style could derive beauty from the basest of materials, for bourgeois ugliness and banality seemed so great as to defeat the illusions of formal perfection and the magic of "style":

What drives one to despair is thinking that, even if it is successful in attaining perfection this [scene in Madame Bovary] can only be acceptable [passable] and will never be beautiful because of its very subject [or content-à cause du fond même]. I

3. Ibid., 338-39. 
do the work of a clown; but what does a tour de force prove after all? No matter: "God helps those who help themselves." The cart is, however, at times quite heavy to be extricated from the mud. [July 12, 1853 ]

One could multiply quotations that impugn the idea that pure art was for Flaubert a simple ideology, doctrine, or credo. But for him art was nonetheless infused with a genuine pathos of belief that was contested but not simply eliminated by selfdirected irony and doubt. Pure art was in this sense a surrogate for a noble religious ideal of transcendence that required a turning away from the ordinary world and a quest for the absolute. The object of belief could, however, only be entertained in a threatened way in the modern world. Secularization itself furthered the tendency of a desire for transcendence to merge unsettlingly with the possibility of transgression. And Flaubert at times defended the critically transgressive and insistently marginal status of the artist in extreme and almost selfnugatory terms.

At the present moment I believe that a thinker (and what is an artist if not a triple thinker?) should have neither religion, country, nor even any social conviction. Absolute doubt now seems to me so completely substantiated that it would be almost silly to seek to formulate it. . . . Yes, it would be a relief to vomit out all this immense contempt that fills the heart to overflowing. What good cause is there these days to arouse one's interest let alone one's enthusiasm? [April 26, 1853]

That socialism was not the good cause evoking enthusiasm was a judgment rarely qualified by Flaubert.

They have denied suffering, they have blasphemed threequarters of modern poetry, the blood of Christ which is active in us. Nothing will extirpate it, nothing will dry it up. The point is not to dessicate it but to make it turn into streams. If the sentiment of human insufficiency, of the nothingness of life were to perish (which would be the consequence of their hypothesis), we would be more stupid [bêtes] than birds, who at least perch in their trees. [September 13, 1852] 
Here, in a vitriolic reaction to the socialists which takes a markedly metaphysical turn, Flaubert moves from doubt to a pathos of belief having Christian overtones. And only a comma separates the sentiment of human insufficiency from more extreme nihilistic leanings. Flaubert saw socialism as an aggravation of the illness it purported to cure: it was the climax of vulgar materialism and indiscriminate leveling.

Have patience, when socialism is established, we will arrive at the peak of this genre [the sufferings of the artist]. In this reign of equality - and it is approaching-one will skin alive all those who are not covered with warts. What difference do Art, poetry, and style make for the masses? Give them vaudeville, treatises on work in prisons, on worker cities and the material interests of the moment, yet. There is a permanent conspiracy against originality,- - this is what must be crammed into their brains. The more you have of color and relief, the more you offend them. From whence the prodigious success of the novels of Dumas? It's because to read him you need no initiation. The action of the novels is amusing. One is distracted while one reads them. Then, the book once closed, since no impression remains with you and all of it has passed by like clear water, you can return to business. Charming! [January 20, 1853]

The most modulated kind of statement to be found in Flaubert on the topic of the social responsibility of the artist and of art is represented by the following: "I am not in the least insensitive to the misery of the poor classes, etc., but in literature there are no good intentions. Style is everything" (January 15 , 1854).

But there were numerous indications in Flaubert that "style" -like originality itself-was elusive, inadequate, difficu't to define, and far from immune to doubt. In addition, Flaubert could turn doubt upon himself and see its sources in the more opaque parts of his life.

You know that I'm a man of passion and weakness. If you could only know the invisible nets of inaction which enmesh my body and all the mists which befog my mind. I sometimes 


\section{Madame Bovary on Trial}

feel so much weakness that I could die of weariness when I've got to do anything, and it is only by the greatest effort that I can grasp even the clearest idea. My youth drugged me with some kind of opium of boredom for the rest of my life. I hate life! That has escaped me in spite of myself-well let it stand! Yes, life, and everything which reminds me that I must endure it. [October 21, 1851]

Along with his radical doubts about modern society that shaded into a general hatred of life, Flaubert was tormented by the question of his own originality and by the possibility that even he would be contaminated by the practices of popular novelists catering to collective stupidity. Given his bourgeois subject matter, he might come to resemble Dumas, Alphonse Karr, or Paul de Kock. ("What I write at present risks being of the stamp of Paul de Kock, if I do not put it in a profoundly literary form" [September 13, 1852].) The work of the "realists" Edmond Duranty and Jules Husson Champfleury seemed mediocre to him. Champfleury, seen by many contemporaries as the greatest novelist of his time, had published Les Bourgeois de Molinchart just before the appearance of Madame Bovary. Sainte-Beuve accorded to it more unqualified praise than he saw fit to bestow on Madame Bovary-a fact that substantiates Proust's indictment of Sainte-Beuve as a critic who betrayed his public trust by habitually touting inferior work to the detriment of significant art. Flaubert himself had read segments of Champfleury's Madame d'Aigrizelles that were published in 1854, and they led him to compare Champfleury to Balzac: "As far as style is concerned, not strong, not strong [pas fort, pas fort]. . . . I have reread Eugénie Grandet. It is really beautiful. What a difference in comparison with that guy Champfleury" (August 5, 1854).

For Flaubert the poles of the contemporary novel were represented by a Paul de Kock at one extreme (that of the technically slick best seller) and by Balzac at the other. Balzac was great, but Flaubert did not want to emulate his successes. He sought different challenges in writing-challenges Balzac seemed to ignore both at his peril and as a sign of his glory. Balzac resorted to an inflation of mediocre subject matter, 
pandered to sensationalism, and relied upon the sure-fire techniques of the popular novelist. ("What a man Balzac would have been, had he known how to write" [December 16 or 17 , 1852].) But Balzac had the verve and spontaneous power that more than excused his deficiencies. With the benefit of hindsight, one might speculate that an "anxiety of influence" prevented Flaubert from appreciating how Balzac at times achieved "experimental" effects through hyperbole supplementary to those Flaubert brought about through minimalization and irony. ${ }^{4}$ Flaubert, however, was manifestly preoccupied less with an anxiety of influence than with an anxiety of impoverishment, exhaustion, and impotence. He had the fear of being a latecomer or epigone-the recurrent fin-de-siècle malaise. He saw Balzac and, especially, Hugo as the last of a vanishing breed. Indeed he could address this problem in ways one might expect more from (or even apply to) a critic such as Sartre than from Flaubert himself:

What is characteristic of great geniuses is generalization and creation. They encapsulate diverse personalities in a single type and bring new personages before the consciousness of humanity. Don't we believe in the existence of Don Quixote as in that of Caesar? Shakespeare is formidable in this respect. He was not a man but a continent; there were in him great men, entire crowds, landscapes. Writers like him don't have to worry about style; they are powerful in spite of all their faults and because of them. But as for us, the little people, our value depends on perfected execution. Hugo, in this century, will rout everybody, even though he is full of bad things: but what lung-power! I will here risk a proposition that I wouldn't dare utter anywhere else: that very great men of ten write very badly-and bravo for them. To discover the art of form, one should not go to them but to writers of the second order (Horace, La Bruyère). One must learn the masters by heart,

4. One might even observe that, in Sarrasine, Balzac showed uncanny reserve in not naming l'indisable which Roland Barthes, despite his preference for post-Flaubertian experimentalism, found no difficulty in identifying in trenchantly univocal and rather "classical" terms. Barthes reads Balzac in too "readerly," in order to rewrite him in too "writerly," a fashion. See $S / Z$ (Paris: Editions du Seuil, 1970). 


\section{Madame Bovary on Trial}

try to think like them, and then take leave of them forever. To learn technique, it is more profitable to go to the erudite and skillful. [September 25, 1852]

Here one seems very far from the portrait of Flaubert as the narrow-minded stylistic perfectionist who made pure art into the nihilistic sublimate of an unqualified death wish. Self-doubt converted Flaubert's option into a strategy faute de mieux which rested, if anything, upon an underestimation of his own talent and achievement. In many ways, it would be most accurate to say that Flaubert both intensely believed in art as a vocation and saw his own labors as the work of a clown.

At times, however, the vilification of the bourgeois age did induce faith in a saving remnant or aesthetic elite who would hold an imperilled torch aloft in a blind and inhospitable world.

What crapulous low-life these peasants are! Oh! How I believe in race! But race no longer exists! Aristocratic blood is exhausted; its last globules no doubt have coagulated in a few souls. If nothing changes (and this is possible), perhaps before a half-century has passed, Europe will languish in great shadows and those somber epochs of history where nothing shines will return. Then a few, the pure, will keep among themselves, sheltered from the wind and hidden, the imperishable little candle, the sacred fire, where all illuminations and explosions come to take flame. [March 25-26, 1853]

At most, Flaubert was able to situate his own time in a cyclical vision of history that held out a faint promise of renewal for the future. And here his own option was clearly a lesser one chosen for want of something better.

There are two kinds of literature, that which I shall call national (the better one) and then the lettered, the individual. For the realization of the first, one must have in the masses a fund of common ideas, a solidarity (which does not exist), a bond; and for the entire expansion of the other, one must have liberty. But what may one say and concerning what should one speak now? Things will get worse; I wish and hope for it. I prefer nothingness to evil and dust to rotten- 
ness. And then there will be renewal! Dawn will come again! We shall no longer be around. What difference does it make? [December 28, 1853]

How one might get from the second to the first condition while retaining elements of freedom and criticism was not Flaubert's concern. He contented himself with apocalyptic anticipations and rare hopes for a renaissance after his passing. His more famous and immediate wishes for redemption in the present were located in a cult of Art that of ten was separated by a thin line from nihilism.

Humanity hates us. We do not serve it, and we hate it because it injures us. Let us love one another in Art as mystics love one another in God, and may all else pale before this love. . . Lovers of the Beautiful, we are all banished ones. And what joy we feel when we encounter a compatriot in this land of exile. . . O Oh! practical men, men of action, sensible menhow I find you inept, asleep, blinkered! [August 14 and 16 , 1853]

This attitude fostered an escape from politics in any ordinary sense, and it induced Flaubert's most quoted invocations to pure art.

One must shut oneself off and pursue with lowered head one's work-like a mole. If nothing changes, there will be formed in a few years guilds [compagonnages] more tight-knit than all secret societies. Above and beyond the crowd, a new mysticism will grow and elevated ideas will sprout up in the shade and on the brink of precipices, like fir trees.

But a truth seems to me to emerge from all this. It is that one has no need of the vulgar, of the numerous element of majorities, of approbation, of consecration. 1789 demolished royalty and nobility, $184^{8}$ the bourgeoisie, and $185^{1}$ the people. There is no longer anything other than a low-life and imbecilic mob. We are all plunged at the same level in a common mediocrity. Social equality has passed into our minds and hearts. One makes books for everybody, Art for everybody, science for everybody, as one builds railroads and public heating rooms. Humanity is seized by moral abasement, and I 


\section{Madame Bovary on Trial}

have a grudge against it because I am part of it. [September 21-22, 1853]

In this context, one purpose of art was demoralization of the common reader. As early as September 4, $185^{\circ}$, Flaubert envisioned a Dictionary of Received Ideas whose preface "would explain how the work was intended to reestablish the public's links with tradition, order, and social norms, and [be] written in such a way that the reader couldn't tell whether or not one was putting him on [si on se fout de lui]." Art for the artist would function as an extreme ritual of purification from the pollution and ugliness of bourgeois or, perhaps, human reality. And it would give him an invidiously privileged access to a realm of beauty conceived as a secular surrogate or fetish for an absent sacred object. Art would negate or annihilate reality in order to permit an abstract and absolute transcendence toward pure formal beauty. Its goal would ultimately be the notorious "book about nothing":

What seems beautiful to me, what I should like to write is a book about nothing [un livre sur rien], a book dependent on nothing external, which would be held together by the strength of its style, just as the earth, suspended in the void, depends on nothing external for its support; a book which would have almost no subject, or at least in which the subject would be almost invisible, if such a thing is possible. ... From the standpoint of pure Art one might almost establish the axiom that there is no such thing as subject, style in itself being an absolute manner of seeing things. [January $16,185^{2}$ ]

Thus subject or content is minimalized so that form, identified with style and beauty, may be raised to the heavens. The qualifications in Flaubert's formulation indicate that the dream is an impossible one. But the goal here is relatively clear: the reduction of content (understood as irremediably ugly and unsalvageable) and the identification of style with autonomous form. Life, moreover, is on the side of irremediably ugly content and opposed to form, style, and beauty: "Life is such a hideous thing that the only way to put up with it is to avoid it. And one avoids it by living in Art" (May 18, 1857). Or again: 


\section{Flaubert's Projects: Pure Art and Carnivalization}

"Oh! Our ivory towers! Let us climb them in our dreams, since the hobnails of our boots keep us anchored here below!" (January 29, 1854). A pure art of detached dreams might take a linguistic turn and entail the metamorphosis of art into a variant of pattern practice: "I would like to produce books that require only the writing of sentences (if I may put it that way), just as in order to live it is enough to breathe" (January 25, 1853). The objective correlative of art as a formal organism unto itself was an image from the realm of the inorganic-a material analogue of the abstract: a blank wall.

I remember having had flutterings of the heart, to have felt a violent pleasure in contemplating a wall of the Acropolis, an entirely blank wall. . . . Well! I ask myself whether a book, independently of what it says, can produce the same effect. In the precision of its assemblages, the rarity of its elements, the polish of its surface, the harmony of the whole-is there not an intrinsic virtue, a kind of divine force, something eternal like a principle? (I speak as a Platonist.) [April 13, 1876]

The Platonic substantialism guardedly referred to in a reserved aside pointed to the multiple functions of the concept of form. One of the most influential of these was of course the idea of an autotelic or self-referential art. This art seemed to require an author of sovereign impersonality whose responsibility for his work would be both total and unlocalizable.

The author in his work should be like God in the universe, present everywhere and visible nowhere. Art being a second nature, the creator of this nature should act by analogous procedures. One should feel in all the atoms, in all the aspects, a hidden and infinite impersonality. The effect for the spectator should be a sort of astonishment. [December 9, $\left.185^{2}\right]$

The impersonality or impassivity of the author (narrator?) did not imply the lack of personal convictions in the man. On the contrary, an active discipline or ascesis was required to modify or suppress convictions that threatened to dominate art in unmediated ways: 


\section{Madame Bovary on Trial}

As for my "lack of conviction," alas! Convictions suffocate me. I burst with repressed anger and indignation. But in the ideal that I have of Art, I believe that one ought to reveal nothing of oneself, and that the artist should no more appear in his work than God in nature. Man is nothing, the work is everything! This discipline, which can take its departure from a false viewpoint, is not easy to observe. And for me, at least, it is a sort of permanent sacrifice that I make to good taste. It would be quite agreeable for me to say what I think and to alleviate Mister Gustave Flaubert by phrases; but what is the importance of Mister Flaubert? [December 20, 1875]

It is significant that this late letter is written to Georges Sand, and Flaubert is combatting an overly direct and didactic notion of committed art. But it is noteworthy that objective art is defended in the same terms that others (such as Max Weber) would use to defend objective social science. Aspects of this letter indicate, moreover, that the practice of disciplined selfrestraint could become ascetic self-denial and join up with a wish to be godlike. As Flaubert put it over twenty years earlier: "When will one write history as one ought to write a novel, without love or hatred for any character? When will one describe facts from the viewpoint of a superior joke [une blague supérieure], that is as the good Lord sees them from on high?" (October 8, 1852).

Here, in a magnificent feat of legerdemain, "scientific" objectivity fuses with a superior joke, and art comes to resemble both science and religion as the sovereignly impersonal authornarrator assumes the transcendentally ironic position of a hidden God. Indeed Flaubert's numerous statements of doubt, self-doubt, and despair are counterbalanced by affirmations of fanatical faith in art.

One does nothing great without fanaticism. . . Fanaticism is faith, faith itself, ardent faith, that which creates works and is active. Religion is a variable conception, an affair of human invention, finally an idea; the other is a sentiment. . . . In Art as well, it is the fanaticism of Art that is the artistic sentiment. Poetry is only a way of perceiving external objects, a special organ which filters matter and, without changing it, transfigures it. [March 31, 1853] 


\section{Flaubert's Projects: Pure Art and Carnivalization}

At times the transcendental vision of art as surrogate religion which negated reality gave way to a more mystical and pantheistic notion of merging with the world. Here it would be the artist rather than the object that was transfigured through empathetic identification. Art might then still be seen as a refuge, but it would be a refuge at one with the world, and the sorts of works it called to mind led, as we shall see, in unexpected directions.

I am turning toward a kind of aesthetic mysticism (if those two words can go together), and I wish it were more intense. When you are given no encouragement by others, when the outside world disgusts, weakens, corrupts, and stupefies you, decent and delicate people [gens honnêtes et délicats] are forced to seek somewhere within themselves a more suitable place to live. If society continues on its present path, I think we shall once again see mystics, such as existed in all dark ages. Unable to spend itself, the soul will become concentrated. The time is not far off when there will be a resurgence of universal languishing, beliefs in the end of the world and the expectation of a Messiah. But lacking any theological foundation, what will be the basis of this enthusiasm that is ignorant of itself? Some will look to the flesh, others to old religions, still others to Art; and Mankind, like the Jews in the desert, will adore all sorts of idols. People like us were born too soon. In twenty-five years, the point of intersection will be superb in the hands of a master. Then prose-prose especially, the younger formcan play. Books like the Satyricon and The Golden Ass will return, but overflowing psychically as those overflowed sensually. [September $4,185^{2}$ ]

Flaubert's sense of the problems created by the meeting of enthusiasm and a manque de base théologique seems prophetic. What is noteworthy is that art is situated among other possible responses to modern disorientation without being given any apparent privilege. At the very least, this view would indicate Flaubert's critical awareness of the partially symptomatic nature of what he at times defended as a solution in more unguarded and fanatical terms. And the works he heralds as avatars of the future-works of the declining Roman Empire with which he of ten compared the modern world-had a distinctive character as carnivalesque, Menippean satires. 


\section{Madame Bovary on Trial}

Indeed, as we have seen, Flaubert at times saw pure art less as a secular surrogate for the sacred than as a compensatory pis aller for an epigone. And he could view form itself as a check or antidote to his mystical inclinations as well as a preservative against nervous disorder, itself somehow linked with what Freud would term the "oceanic feeling." Form in this respect would not be a sublimate of a "death instinct" but a prophylactic force for life counteracting a temptation to faint existentially in a life-denying swoon. "Without a love of form, I would perhaps have been a great mystic. Add to that my nervous attacks, which are only the involuntary declivities of ideas, of images. The psychic element then leaps across me, and consciousness disappears with the sentiment of life" (December 27, 1852).

Pure art could also move from the status of an object of faith or belief to that of an unrealizable utopia or critical fictioneven to that of an illusion. As Flaubert put it in one terse, oxymoronic sentence: "I love art and yet I do not believe at all in it" (March 20, 1847). In addition, Flaubert realized that the content or subject matter would necessarily threaten the purest of forms with contagion and expose the writer to contamination by the very bourgeois stupidity he treated in his writing. One could not entirely divorce the parodic citation or mention of cliché from its use, and the writer touching cliché would have to dirty his hands and face the threat, perhaps the temptation, of embourgeoisement and bêtise. The very practice of writing would render it impossible to lead the purely dualistic existence that Flaubert at times advocated in enjoining the writer to "live like a bourgeois and think like a demigod" (August 21, 1853).

One could adduce many quotations from letters in which Flaubert rejected the pure opposition between content and form and suggested a complex notion of style as a practice of writing that could not be identified with pure formalism or self-referentiality. Then style became something more visceral that could not entirely transcend materiality or allow an identification of the materiality of language with the imaginary. "'Poet of form!' That is the favorite term of abuse hurled by utilitarians at true artists. For my part, until someone comes along and separates the form and the substance of a given sentence, I 
shall continue to maintain that that distinction is meaningless. Every beautiful thought has a beautiful form, and vice versa" (September 18, 1846).

This last statement could be read as probingly dialectical or as utterly banal. What is perhaps more to the point is that "style" in its manifold and at times incompatible meanings often replaced and displaced pure formal art as Flaubert's goal. Style might mean form in some transcendent sense. But, on a more mundane and technical level, it might mean continuity of parts and surface polish. It might also be substantialized as a Platonic idea. "Sustained harmony of style" was presumably a discovery of the moderns (June 6-7, 1853). As I have already intimated, Flaubert's novelistic practice in Madame Bovary might more aptly be termed a dual or plural style which contested without entirely denying notions of unity and harmony in writing. And, even in the letters, the definition of style was itself elusive, perhaps "unsayable" or communicated only indirectly, yet organically felt. "What after all is style? In what does it consist? I no longer know at all what it means. But yes, but yes, nevertheless! I feel it in my stomach" (January 29-30, 1853).

What has been the purpose of the battalions of quotations I have drawn from Flaubert's letters at the risk of falling into a displaced repetition of Sénard's strategy at the trial? My goal has been to bring out the complex and often divided nature of Flaubert's "project" of pure art itself, even before one turns to the further complications introduced by another important "project" enunciated in the Correspondance. This strategy was necessary in view of the tendency to see "pure art" in rather restricted terms and to confine it within one-dimensional interpretations.

Before turning to the question of how the already intricate project of pure art was further complicated by at least one other project in the letters and, even more so, by the way the projects relate to the functioning of Madame Bovary as a text, I shall examine the interpretation of Jean-Paul Sartre. For Sartre's L'Idiot de la famille, despite its own convolutions, presents a line of argument that reduces the uneasy and often self-questioning heterogeneity of Flaubert's understanding of art to a rather circumscribed set of issues. Sartre is both highly selective 


\section{Madame Bovary on Trial}

in his use of Flaubert's letters and quite pointed in his interpretation of them. His dominant interpretation, I think, applies most cogently to the extremely lapidary articulations of the ideal of pure art in Flaubert, often ignoring or underemphasizing the relevance of qualifications or hesitations in the letters as well as the difficulties in referring "projects" to the workings of a text such as Madame Bovary.

In pursuing this line of inquiry, I shall try to be sensitive to the complexities of Sartre's own account that mitigate the force of certain of his theses, especially with reference to the issue of Flaubert's style. But I shall by and large confine my analysis to one stratum of Sartre's text-its thematic or "thetic" level-and only mention the tensions between it and Sartre's own practice or "style" of writing in L'Idiot. For my purpose here is not an intertextual reading of Madame Bovary and L'Idiot. It is rather the more limited attempt to offer a (partial) reading of Madame Bovary which tests critically the extent to which the theses and arguments of L'Idiot are informative for an interpretation of the novel and for an understanding of the relations among the novel, the trial, and Flaubert's projects.

Hence I shall approach Sartre's study through a set of specific questions. What is Sartre's view of the meaning of pure art? What is the existential basis of Flaubert's aesthetic project? What is the bond between Flaubert's life and his times? What are the more particular features characterizing the horizon of expectations of Flaubert's contemporary readership? How does Flaubert relate to the problem of commitment and, by implication, to the issue of the political significance of the way we read him? How do the general features of Sartre's argument apply to a "practical criticism" of Madame Bovary which Sartre, in his completed volumes, only adumbrates? What are the value and the limitations of Sartre's arguments as they apply to Flaubert's projects and to the reading of Madame Bovary? In addressing these questions, I shall defer treatment of what is perhaps Sartre's most interesting discussion of Flaubert's "style" to a later chapter. ${ }^{j}$

In Sartre's interpretation, pure art is the post-romantic

5. See Chapter 5 . 
ideology of Flaubert and his generation for whom romantic ideals were hopelessly compromised and bourgeois realities entirely unlivable. The musings of Musset, Lamartine, and Vigny seemed vapid and fit only for parody. A premature political attempt to realize ideals collapsed in the 1831 revolt of lycée students against school authorities in Rouen (a revolt which Flaubert, despite his extensive writing on his youth, does not even mention). The bad faith and hypocrisy of their liberal parents were revealed to the schoolboys when the older generation betrayed their anticlerical principles to line up with established authority and to preserve political ties with Royalist forces, even if it meant abandoning their children in the boys' protest against compulsory confession at school. This revolt was fresh in the schoolboys' memories when Flaubert entered the lycée in 1832. And in 1839 Flaubert himself took a leading part in another protest which centered around the quality of teaching and the intimidation of students at the lycée.

The blow dealt to political idealism by 1848 and its aftermath was even more far-reaching and complex, and it reinforced the disillusionment of the 183 os for Flaubert. In this thoroughly disabused environment, Flaubert could accept the results of the Romantic agony as foregone conclusions. His repeated plaint was that he was old before his time, and his fictional creations could be presented as existentially dessicated without having to earn their inner emptiness as the dry fruit of experience.

The term "realism" is for Sartre little more than a mask or smoke screen for aesthetic tendencies of a sort diametrically opposed to realism. The puzzle is how people at the time could identify as realistic what had such a different incentive. The animus of pure art was a systematic derealization of reality and an impossible attempt to realize the imaginary. It was no simple and anodyne doctrine of escape from an uncongenial world. It was rather a hate-filled ideology which was suicidal and genocidal to the core. If the bourgeoisie alone were the object of the artist's nihilating practice, pure art might have been a trojan horse with progressive political implications-at least from the Marxist perspective which Sartre attempts to make his own. But the object of vilification and systematic demoralization was the human being in general-the very man in man. A passive 
and "feminine" vindictiveness excluded all possibility of active confrontation with the sources of alienation in the real world. Proponents of pure art were in Sartre's oft repeated phrasethe leitmotif or eponym of his study-"knights of Nothingness." Their nihilistic gambit was to save or redeem themselves by annihilating reality and any hope for realistic betterment in the world through political revolution. Their use of the imagination was as an uncompromisingly satanic force for abstract negation and escape. Pure art was in this sense both the sublimate of a universal death wish and the medium of a self-centered Erlösungspiel or artistic drama of personal redemption. Flaubert was the most genuinely nihilistic of a post-romantic generation whom Sartre describes as "a black feodality for whom the principle of Beauty is hidden but of which Artists are imaginarily the knights of Nothingness [chevaliers du Néant]. The relation of Flaubert to reality is imaginary destruction."

The specific link between art for art's sake as an aesthetic ideology and the personal history of Flaubert was a pathological condition or "neurosis" which Sartre interprets less in causal than in hermeneutic terms. Indeed his thesis becomes less controversial if one substitutes for the loaded term "neurosis" the notion of deep-seated (or "lived") existential problems, for-aside from the negative connotations apparent in Sartre's argument-he often seems to identify the two. And he will even, in the fashion of R. D. Laing, rehabilitate "neurosis" in contrast to the easy conformist compromises of the youthful poète maudit turned respectable bourgeois (for example, Ernest Chevalier, a childhood friend of Flaubert). But "neurosis" acquires its more negative characteristics when it is correlated with merely imaginary destruction in contrast with Marxist commitment to change in the real world.

The strategy of derealization of the real and realization of the imaginary as the work of the imagination was a "neurotic" project that became a collective norm as well as Flaubert's accepted fate ("option subie"). L'art pour l'art was a displacement and a secularization of a religious framework whereby neurosis

6. L'Idiot de la famille, 3 vols. (Paris: Gallimard, 1971-72). My references to L'Idiot are to volume and page number, and translations are my own. 
filled the space left empty by the disappearance of a religious institution. Its meaningful role was to induce total dedication of the votary-artist to a quasi-monastic, secular asceticism that justified separation from, and disdain for, the "real" world. Art became a fetish as the replacement for a missing divinity, and it was existentially invested with the fallout left by the explosion of the sacred. Pure art was, in this sense, one of the residues of what Max Weber diagnosed as the Protestant Ethic. (Comparable in "fetishistic" status and equally dubious from Sartre's perspective, however, is the type of "value-neutrality" in science that Weber at times defended: pure art for Sartre is strictly analogous to "positivism" in its nature and functions.) L'art pour l'art was a "spirit" ostensibly hostile to the spirit of capitalism and bourgeois commercialism-but one readily accommodated to the latter in a larger political and social world where an aesthetics of pure art was impotent in transforming reality. It was also charged with more sinister and covert functions: those of expressing (and masking) the self-hatred and generalized hostility of a conquering bourgeoisie that by 1848 had little left of its formerly heroic mission.

Flaubert himself was the man for his times, as Madame Bovary was apparently the book answering the needs of its epoch. Flaubert in Sartre's estimation was a genuine hysteric who imitated schizophrenia. His lived experience (vécu) provided him with the existential depth that in subtle ways made his art an authentic response to the hidden needs of his readers, while the play-acting at madness of figures such as Leconte de Lisle destined them to a minor status. The peak event (or "identity crisis") in the life of Flaubert was his famous fainting fit at Pont L'Evêque in January of 1844 . Here, in dramatic and quasiritualistic fashion, Flaubert fainted away from a hated "reallife" career in law and into an "imaginary" life as a writer and artist. The event had almost religious meaning as a conversion experience and as the only available answer to the word of Flaubert's own godlike father, Achille-Cléophas, who thought little of his younger son and found literature a pursuit fit only for the weak and the feminine. 1844 was also a proleptic substitute for 1848 and a herald of the Second Empire. Flaubert could be literarily ahead of his time because he was literally 


\section{Madame Bovary on Trial}

behind it-fixated by his crisis of 1844 and prepared by his "lived experience" to furnish what the bourgeoisie after 1848 really wanted: an ideology of antihuman hatred masquerading as realism. "Gustave in ' 44 already constitutes himself as the subject of the Second Empire. This is why he missed the rendez-vous of '48. Everything happens as if his revolution of February [1848] took place in January ' 44 " (III, 665).

"The most profound meaning of [Flaubert's] neurosis" is what Sartre terms the game of "loser wins" (II, 1952). Flaubert was an almost intentional loser in real life in order to become a winner in the realm of art and the imaginary. His loss in life entailed sequestration, premature old age, vague illness, the habits of a crotchety old maid, and an abhorrence of practical activity. His victory was imaginary, and its significance resided in a secularization of religious values. His "neurosis" was itself meaningfully constitutive in relation to his aesthetics. The decline of orthodox religion and the unavailability of the monastery made neurosis the via regia of the artist in quest of ascetic discipline and a private ritual of redemption. The negation and denial of the world brought the faint promise of salvation to the one who "absented" himself from complicity in reality.

Life deranges; it risks, through its passions without force and its cares without grandeur, to turn the artist aside from his true task which is to perpetuate the shipwreck of the world through style. . . . Living is a distraction. . . . One day writing to Louise [Colet], [Flaubert] is astounded: how can Leconte de Lisle, an artist, waste two years in stormy and disappointing love affairs to the point of forgetting his Art? His stupor might make one laugh, but it portrays him. Why does one have to love when the unique matter of importance is to write, and style, an absolute point of view, never ceases to steal away? "Think of style," he tells the Muse, "think of it always." One would say one has a believer speaking of his God. That is the case, and it's worse still. For this uninterrupted meditation on language takes place in the throes of anguish and disgust. This Christian believes he is damned. His only chance of salvation is time. A uniform time, empty of all content, which has the savor of boredom: boredom whose each instant resembles the preceding one and which he can profitably use to 
invent a form adequate to his unique subject, decided upon since adolescence and never before treated. [III, 24]

This unique subject, as we shall see, is how to fashion a style indirectly communicating a neurotic experience that is literally unspeakable or unsayable (indisable) and that is lived in silence. Language is the impossible means of communicating this experience, and Flaubert's relation to language is both vital and deadly. The troubled, indeed anguished, relation of Flaubert to language began in infancy when he was the passive object spoken about but unable to speak. Consubstantial with Flaubert's neurosis was a profoundly passive relation to language: he never outgrew the feeling of being its spoken object rather than its active speaker. Language came to him from the outside and put words into his mouth or under his pen-words he labored on like a fanatical, masochistic, and sadistic saint but words that never became for him practical media or instruments in changing the world.

As a child of seven, Flaubert was unable to read. This fact both induced the belief of his father that Flaubert would never amount to anything and epitomized the relation Flaubert would have toward the word throughout life. He would never read. He would only reread-and in a way that revealed an inability to absorb what he read. Reading was a pretext for empty dreaming. His legendary labors to arrive at le mot juste were refinements of a nihilistically passive relation to language. "Life is 'a story full of sound and fury, told by an idiot.' This sentence would not pass for the last word of Shakespeare. It is the last word of Flaubert" (II, 2039).

Flaubert's "estrangement" from language has, for Sartre, "only one explanation: there is no common measure or mediation between the subjective existence of Gustave and the universe of significations: these are two perfectly heterogeneous realities of which one at times visits the other. . . Life and words are incommensurable" (I, 26). We shall return to the elaborate implications Sartre draws from this view with respect to the crucial problem of Flaubert's style. Suffice it to say at this point that the "bad insertion into language" which Flaubert experienced may be traced to his childhood, and it created a 


\section{Madame Bovary on Trial}

condition the adult would take up as his own. Flaubert was forever the "signified" of language but never in the liberated position of active "signifier."

Reduced to the contemplation of his passivity, the child cannot know that he has the structure of a sign and that the living transcendence [dépassement] of the lived [vécu] is in him, as it is in everyone, the foundation of signification. Thus language comes to him from the outside: the signifying transcendence is the operation of the other and is accomplished by a signification that determines him from the outside. . . . Words are things that the course of lived experience ferries along; he will have much difficulty in making them the living instruments of his own transcendence toward the exterior and will never completely succeed because he has been passivized [passivisé] by maternal cares. [I, 157]

The maternal cares to which Sartre refers are the product of his own elaborate speculation about how Flaubert's mother must have treated the infant Flaubert given Sartre's interpretation of the way Flaubert turned out-a speculation Sartre himself labels a fable, but a fable whose truth value is presumably redeemed by its insertion into the dialectically "totalizing" hermeneutic of existential Marxism. Flaubert's mother, we are told, handled him with painstaking, formalistic meticulousness but without genuine love. She in a sense treated the infant Flaubert in the way Sartre believes Flaubert treated the characters and objects in his stories. Flaubert's passive, objectified, reified relation to language was solidified by the manner in which his mother related to him as an infant-an imprinting which he assumed in his attitude toward his fictional world. The mother was a dutiful but unloving formalist in handling the infant: the adult would be a fanatically dutiful but genocidal formalist in handling fiction and "derealized" language.

How was Flaubert the man for his times, if not the man for all capitalistic seasons? "A work of hatred-that is, one that takes hatred as its point of view-speaks the truth of the epoch" (III, 325). Flaubert's work has for Sartre the predominantly symptomatic function of reinforcing capitalism and justifying alienation. But it is not simply symptomatic. It actually aggravated conditions that informed it and to which it responded. It 


\section{Flaubert's Projects: Pure Art and Carnivalization}

did not so much reflect as articulate and exacerbate the most hateful and destructive animus of the times. The very understanding of Flaubert's art as realistic both bespoke a nihilistic sense of reality and concealed the nature and implications of that apprehension under a misleading label.

Thus the aesthetic of art for art's sake was itself the neurotic collective ideology of post-romanticism, and it normatively created the expectation that the artist would be neurotic. "From $185^{\circ}$ to the end of the century, one had to be crazy to write" (III, 41). In the eighteenth and, even more, in the seventeenth century, the author by contrast was supposed to be an "honnête homme" who strictly observed certain rules and was integrated into society (III, 41). In cases such as those of Rousseau or Pascal, a diagnosis of neurosis might be justified. But neurosis "was useful indirectly; one wrote against one's illness, in spite of the trouble, as did Rousseau, and not thanks to it. The essential point is that, in integrated societies, the psychoneurotic element, if it exists, is never taken as the goal of the artist and even less as the rule of his art" (III, 43). If individual neurosis exists in an "integrated" society, it is for Sartre annulled in what he calls, following Hegel, the "objective Spirit" of the time-its objectified common culture. Flaubert's time, on the other hand, demanded and expected the artist to be neurotic, for the collectivity was itself psychopathological.

At this time, the condition for creating art is to be neurotic. Not in any which way but in a precise manner which we want to define. The objective movement transforms culture on the basis of deeper transformations-but also as a function of traditions and laws proper to the cultural sector-a product of norms so rigorous and so contradictory that the contemporary movement of Art can realize itself as a determination of the objective Spirit only in the form of Art-Neurosis. This does not mean that works are neurotic but that the literary doctrines as well as the "poetic arts" are and that artists must play at neurosis or be neurotic. And since the literary fact is dual, this means as well that, for the public, reading, while it takes place, becomes a brief, provoked neurosis. [III, 43-44]

Sartre's interpretative move here is to integrate or translate a Marxist theory of alienation into its quasi-Freudian, psycholog- 


\section{Madame Bovary on Trial}

ical counterpart. Thus Sartre feels able to answer in the affirmative a question tentatively raised by Freud toward the end of Civilization and Its Discontents: "If the development of civilization has such a far-reaching similarity to the development of the individual and if it employs the same methods, may we not be justified in reaching the diagnosis that, under the influence of cultural urges, some civilizations, or some epochs of civilization - possibly the whole of mankind-have become "neurotic'?"7

For Sartre an alienated culture does indeed give rise to psychological alienation or neurosis, and unlike Freud he attempts to connect an analysis of the family to a Marxist conception of the larger socioeconomic conditions operative in bringing about modification of "lived experience" in individuals. Indeed Sartre broadly extends a theory of alienation through individual life, collective ideology, and the reading experience. The work itself is presumably not neurotic but, as we shall see, its precise relation to neurosis is difficult for Sartre to define. For the intentional structure of the act of writing must participate in neurosis, and its objective correlative-the art work or textmust be an object of neurotic investments (or what Freud would term "cathexes"). Art must be seen as escaping, refusing, or denying reality, and the structure of reality itself must be definable in clear-cut, perhaps dogmatic, ways.

The essential point [of this art] is to refuse the rigidity of oppositions-because they are the structures of reality-by derealizing them. It is ultimately a question of spontaneously imitating autistic thought. Given the inability to transcend contradictory imperatives, one makes them ceaselessly pass into one another and one transforms them into double binds [tourniquets]. One constructs a logic of Nothingness [Néant] that goes from the realization of the unreal to the derealization of reality. This makes impossibility the fundamental condition of every enterprise. One thinks on several levels, in several voices. On the surface, one attempts a chef-d'oeuvre because it is always possible to create one. More profoundly one undertakes it because it is impossible and in order to dream of it. . . [The poet] founds his merit upon failure:

7. Civilization and Its Discontents, trans. and ed. James Strachey (New York: Norton, 1961), 91 . 
simultaneously aesthetics transforms itself into ethics. Grandeur consists in sacrificing oneself without reserve for causes that are lost in advance. But merit is a requirement. What if the reward were to be won precisely at the moment one thought one lost? What if hard luck [le guignon] were only the visible aspect of election? Depersonalization, rupture with reality, solitude, hypostatized language, misanthropy, selfhatred, the will to fail [conduites d'échec], the quest for the impossible-these neurotic traits are only the means of writing, that is, of continuing literature in an epoch where, far from finding one's liberty in literary autonomy, the writer is alienated in that very autonomy, and writing places itself in question in every written work. The possibility of creating [faire] a work is no longer acquired; before the scandal of an unfindable public and contradictory imperatives, the foundation of Art must be sought in irrationality. [III, 199-200]

In this "can't-win" situation where an impossible victory is sought through failure, the loser can seem to win only if his birth as artist coincides with his death as social agent.

The birth of the Artist through Art of which he is the minister requires-like religion-this precondition: social death. Art, this Absolute, this supreme value, can only be served as a cult by the infirm and the incapable-and no one is an artist who has not given striking proofs of his incapacity. Behind this conception, one of course perceives Christian ideas: Beauty, like a divine fulguration, strikes the heart of the humble and the dispossessed. Conversion is nothing other than a new vision of the world grasped through the secular failure of the convert. [III, 168]

The centuries-old background of art for art's sake is thus Christianity. And "Flaubert writes for a Christian West." Indeed Sartre insists that "we are all Christians, even today; the most radical disbelief is a Christian atheism, that is, it conserves, despite its destructive power, certain directing schemes -for thought, very few; for the imagination, more; but especially for sensibility-whose origin is to be sought in centuries of Christianity of which we are willy-nilly the heirs" (II, 21 24). Whatever our resistance to Christianity, the invocation of idées- 
forces such as ascesis and redemption is a testimonial to a ghostlike heritage. "For an instant, Christians in the imaginary, we march."

But Sartre also finds more local contextual resources for Flaubert's art in his specific historical period. Especially significant were 1848 and the Second Empire. Especially after the failed revolution of 1848 , a post-romantic atmosphere of disillusionment combined with an inability or an unwillingness to carry alienation beyond psychological and ideological bounds. A bar blocked constructive social and political action, and it was reinforced by guilt and hatred in the aftermath of 1848 . A writer in the 1850 s had to reflect and intensify a profound disgust for human nature which both excused particular bourgeois practices and passed in silence over the concrete events of 48. A work was necessary that managed to express the guiltridden, genocidal meaning of 1848 yet also hid it behind that veil of false universality: la condition humaine. Specific bourgeois principles would still be naturalized and universalized as they had been in the more progressively triumphant phase of bourgeois self-assertion, but their ideological value would pass from the positive to the negative. The writer, "in condemning man without recourse, would exonerate the men of ' 48 , even the killers, from all particular responsibility" (III, 418-19).

Thus the writing of the 1850 - and in some sense Madame Bovary as the chef-d'oeuvre of the period-functioned as an intensified reinforcement of the ideological and psychological needs of the time. But it did so in a subtle way-not as a direct reflection of either the true or the false consciousness of the period.

When, from 1849, the knights of Nothingness publish their first works, if the cultivated public adopts them, if it makes them its poets and its novelists, the reason is not that they incite it to a coming to consciousness, nor further that they consolidate its false consciousness in presenting to it its image in a poem or the hero of a novel. The truth is more complex: the artist imposes himself on both the men of talent and the rich because he differs from them radically, both because they comprehend implicitly his purpose and because they arrange to misunderstand; both because they grasp the homicidal in- 


\section{Flaubert's Projects: Pure Art and Carnivalization}

tention which hides itself in its irrealization at least enough to make it serve their end, and because a perhaps inevitable misunderstanding defines him in their eyes as a doctrinaire of realism. These strange and twisted links mean that no writer has so much scorned his public and that none has more completely expressed it-not in its historical truth but in the true pathos which founds false consciousness and ideological nonsavoir. [III, 302]

In this difficult passage, Sartre takes his distance from the dominant thematics of such Marxist theorists as Lucien Goldmann and Georg Lukács. He also tries to go beyond his own earlier understanding of bad faith that could be correlated with a theory of false consciousness. Self-deception is still an issue as he here formulates the problem, but it is not conceived in predominantly rationalistic or narrowly self-interested terms. Rather Sartre's earlier notion of prereflective consciousness is itself intensified and to some extent transformed in an interpretation of lived experience (le vécu) whereby an individual or a group can see something falsely in order to mask a more profound and "genuine" intention. In this sense, what a work expresses is not directly an ideology or a false consciousness; it is a pathos which is in part hidden from social agents but which does serve their class interests-and for which they are ultimately responsible. The pathos in question here is destructive and genocidal in intent.

Sartre will also present the Second Empire, established after the coup d'état of Louis Napoleon in $185^{1}$, as an imaginary realm corresponding to the "derealizing" labors of Flaubert and his aesthetic generation. The Second Empire was a pseudoempire, a superstructure without an adequate infrastructure, a hollow echo of the Empire of the first Napoleon. Indeed Sartre's own use of Second Empire furniture as decor in his early play No Exit gives some sense of the interpretation of the period he would provide in his study of Flaubert.

In the light of his analysis, Flaubert would seem committed to what Sartre in an interview termed "total disengagement and the quest for a formal ideal." ${ }^{8}$ In L'Idiot, pure art as a formal

8. Situations IX (Paris: Gallimard, 1972), 116. 


\section{Madame Bovary on Trial}

ideal takes on the pathos of demoralization, derealization, and annihilation not simply of bourgeois civilization but of the human race. Flaubert is in a sense committed, but his commitment would seem to be the total antithesis of the more normative and progressive commitment advocated by Sartre in What Is Literature?. ${ }^{9}$ It would even seem distant from the more subtle understanding of critical and at least partially constructive commitment traced in "A Plea for Intellectuals." discussion of Sartre's conception of Flaubert's "style," we shall touch upon certain reformulations of Sartre's theory of language as it bears upon the problem of commitment, but even this dimension of Sartre's interpretation takes a largely negative turn. And when Sartre explains himself in an interview in Le Monde concerning the meaning of commitment in Flaubert, he identifies it with a biblical passion for personal salvation and a project of imaginary derealization and totalization-precisely those features viewed in a predominantly negative light in L'Idiot.

Total lack of commitment [le désengagement total] is what appears if one superficially considers everything [Flaubert] wrote. But then one notices a profound commitment on a second level that I would, in spite of everything, call political. Here we have a man who, as one knows, was a proprietor and a reactionary. But if one stops there, one does not do justice to Flaubert. To grasp him truly, one must go to the profound commitment, a commitment through which he tries to save his life. The important point is that Flaubert totally committed himself on a certain level even if the latter implied that he took blameworthy positions in every other respect. Literary commitment is in the last analysis the fact of taking up [assumer] the entire world, the totality. To take the universe as a whole, with man inside it, to account for it from the viewpoint of nothingness, is a profound commitment. It is not simply a

9. Qu'est-ce que la littérature? in Situations II (Paris: Gallimard, 1948), 55-330; Bernard Frechtman, trans., What Is Literature? (New York: Philosophical Library, 1949).

10. "Plaidoyer pour les intellectuels" in Situations VIII (Paris: Gallimard, 1972), 373-455; John Matthews, trans., "A Plea for Intellectuals" in Between Existentialism and Marxism (New York: Pantheon Books, 1974), 227-85. 


\section{Flaubert's Projects: Pure Art and Carnivalization}

literary commitment in the sense that one "commits oneself to make books." As in the case of Mallarmé, who is a grandson of Flaubert, it is a question of a veritable passion in the biblical sense. ${ }^{11}$

This highly equivocal statement can be read as Sartre's final reconciliation with Flaubert and an assertion of "positive" commitment in Flaubert's writings only if one is willing to indulge the myopic desire for consensus at any price which Sartre himself attacked time and again. The tone of voice has changed from the dominant tenor of L'Idiot. This change counts for something, but the terms of Sartre's argument remain very much the same. In L'Idiot, Flaubert was indeed seen as taking up the universe as a whole but only to annihilate it through imaginary "derealization" indentured to a suicidal and genocidal project of seeming self-redemption. Sartre's own overwhelmingly hyperbolic argument accounts for, I think, the most extreme and unqualified assertions of the ideal of pure art in the letters of Flaubert. It brings out their antihumanistic and even nihilistic implications, and it relates them to Flaubert's life and times in a manner that is at least suggestive. But the difficulties in Sartre's approach are many, and they are not overcome by his own hesitations in enunciating given propositions.

Sartre tends to amalgamate Flaubert's letters and his fictional texts in a primarily symptomatic or functionalist reading oriented toward a delineation of the author's life and times. The nature of the functions of literature is often treated with great subtlety, but there is less subtlety in the understanding of the relations among leuers, fictional texts, and inferences concerning individual or collective life. Often Sartre has only the letters or the fiction to go on. But he is quick to extrapolate from them to the life of the author, the expectations of a readership, and the characteristics of collectivities-which he then, in circular fashion, uses to explain the writings. This procedure is facilitated in part (but not completely) by the fact that Sartre devotes the bulk of his attention to the semi-confessional juve- 


\section{Madame Bovary on Trial}

nilia. The analysis of Madame Bovary was to come in a fourth volume that was never completed, and in a moment we shall raise questions about the relatively brief treatment accorded the novel in the three completed volumes. The more general point, however, is that Sartre does not pose as an explicit problem the relation of various kinds of writing to one another and to personal or collective life. By and large in L'Idiot, he simply employs writings in speculating, at times wildly, about the way life was or must have been.

Missing even in those speculations is the question of the relations among the symptomatic, the critical, and the features that exceed these categories of analysis. In the discussion of Flaubert's life and times, Sartre treats almost exclusively the manner in which writings or works of art were not simply symptomatic but aggravating manifestations of the most negative features of the time. (Indeed his bourgeois go beyond the stupid philistines of Flaubert's letters to incarnate the banality of evil as genocidal bêtes.) What is not investigated is the way the symptomatic or aggravating aspects of texts are counteracted by modes of critical disclosure that Sartre himself discussed in What Is Literature?. Sartre apparently does not find these features in Madame Bovary. In his discussion of Flaubert's readership, he does not examine the trial as an empirical instance of conventions in a key social institution that attested to existing horizons of expectation among bourgeois readers. One might, in Sartre's terms, see the trial as a defense mechanism on the part of those unwilling to recognize their own genocidal inclinations, but the view of Flaubert as scapegoat would have to account for the effects I have discussed in terms of ideological crime-effects Sartre is willing to acknowledge in cases other than that of Flaubert.

Yet, if Sartre ideologically insists on seeing man as activeeven at the cost of excessively dualistic oppositions between activity and receptivity-he sees the text and often the writer as passive. How the writer mediates and modifies the obsessions or psychological investments of the author is not extensively explored as a real problem. Indeed one crucial reason for Sartre's rejection of the very notion of text is that he continues to see it in exclusively formalistic terms. 


\section{Flaubert's Projects: Pure Art and Carnivalization}

Flaubert applies himself . . to derealizing language. Far from utilizing it to designate a signified exterior to the Word, he applies his art to making the thing pass into the materiality of the word so that the sentence, sonorous and closed, cut off from its references to the world, tending to pose itself for itself, to become what one today calls a text, refers to all of language and only to it. [III, 605]

Thus Sartre identifies the very materiality of language in Flaubert with the project of imaginary "derealization" of the world and the constitution of a putatively autonomous, selfreferential art. He also equates Flaubert with contemporary theorists who see the text in neo-formalistic terms as the autotelic realm of a fully liberated "signifier." In so doing, Sartre tends to see others as attributing to the text the position of full liberation or freedom that he himself is often tempted to attribute to "man." But the more potent and politically relevant understanding of the text involves a critique both of these identifications and of purely dichotomous oppositions such as those between activity and passivity, signifier and signified. The text is then seen not as a self-enclosed linguistic world but as a use of language or a signifying practice related to other practices in a multiplicity of ways. Sartre himself seems close to this other understanding of textuality when he argues that language cannot be placed squarely either on the side of lived experience (le vécu) or on that of the conceived and knowledge (le conçu)thereby implying that language undercuts his own founding oppositions in a manner that would seem to necessitate an explicit rethinking of problems of a sort Sartre rarely undertakes:

To speak is for everyone an immediate and spontaneous, lived experience to the extent that the spoken word [la parole] is a practice [une conduite]; inversely, lived experience [le vécu] is never pure of words [vierge de mots] and, of ten, resuscitates worn-out designations that aim at it without being truly adequate to it. Thus verbal conduct can in no case be defined as the passage from one order to another. How could this be possible since the reality of living and speaking man is made up at every instant by the melding of the two orders. To 


\section{Madame Bovary on Trial}

speak is nothing other than to adopt and deepen an already speaking conduct, that is, one expresses oneself. [I, 38$]$

The further point would be that writing is also a practice that cannot be divorced from speech on the metaphysical grounds which Sartre will at times invoke. With reference to the issue of "neurosis," it must, however, be noted that Sartre, in his brief allusions to Madame Bovary, does not present this text as a pathological document or morbid case history. Thus he distinguishes it from Flaubert's ordinary life, the collective mentality (or objective Spirit) of his time, and the expectations of his readership. But why he does so is far from clear. Sartre writes that in Madame Bovary "horror is never present. It haunts the book without giving itself to be seen. Ceaselessly aimed at [visée], it escapes. Precisely for this reason, Madame Bovary, as a work, does not enter into the categories of pathology: it does not itself refer one either to the subject who wrote it or to his obsessions" (III, 30).

Presumably the reasons for these assertions would have come in the missing fourth volume of L'Idiot. I think it is plausible to argue, however, that Sartre's difficulty in providing them may have been one reason why the fourth volume itself was never completed. In the existing three volumes of L'Idiot, the references to Madame Bovary are dispersed and rarely go beyond the level of allusions, illustrations of points made on other grounds, or suggestive indications of possible interpretations. And it is difficult to see how the lines of argument laid down in the three earlier volumes could have been extrapolated to furnish a sustained, differential analysis of the novel. Sartre does not manage in L'Idiot to provide the dialectical comprehension of the multiple ways a text interacts with its various contexts that one might have expected on the basis of his arguments in Search for a Method or "A Plea for Intellectuals." 12 We shall see certain consequences of this failure in Sartre's treatment of Flaubert's notion of l'indisable and its relation to "style." To reiterate, Sartre's analysis of the life and times of Flaubert is

12. Question de méthode in Critique de la raison dialectique (Paris: Gallimard, 1960); Hazel E. Barnes, trans., Search for a Method (New York: Knopf, 1963). 


\section{Flaubert's Projects: Pure Art and Carnivalization}

most applicable to one important aspect of Flaubert's project of pure art and, to a lesser and ill-defined extent, to certain features of Madame Bovary as a text. In the latter respect, it would seem to inform the dimension of impersonal, "objective" narration-what Sartre terms the "principe de survol"-and in part the attitude of the narrator toward characters. Here elements of the inhuman distance and even hatred stressed by Sartre do appear-but not in an unqualified way.

In addition, the extent to which Madame Bovary invited neurotic investments on the part of its author and its readers remains a moot issue that is in part decided by the kind of reading one argues for in a critical dialogue with the novel. The paradoxical effect of Sartre's own interpretation may be to facilitate those very investments or types of reading he himself would see as politically reactionary. (Indeed it is remarkable that a certain kind of "poststructuralist" reading-which Sartre would see as antagonistic to his own theoretical position-can arrive by different routes at conclusions about Flaubert that are similar to Sartre's own.) With reference to the readers of Flaubert's own time, Sartre offers no empirical evidence for his thesis. Here his interpretation remains almost exclusively on the level of suggestive coloration. And, with reference to the author-writer, Sartre fails to investigate, or perceives in a restricted way, projects that contest "pure art" in his construction of it.

A second project discussed extensively in Flaubert's letters is what I term (following Mikhail Bakhtin) carnivalization. ${ }^{3}$ This

13. Mikhail Bakhtin, Problems of Dostoevsky's Poetics (Ann Arbor, Mich.: Ardis, 1973), and Rabelais and His World (Cambridge, Mass.: The M. I. T. Press, 1968). See also The Dialogic Imagination, trans. Caryl Emerson and Michael Holquist (Austin: University of Texas Press, 1980). The role of carnivalization in Flaubert has recently been stressed by Arthur Mitzman who provides much useful contextual information concerning Flaubert's life and times. "Roads, Vulgarity, Rebellion, and Pure Art: The Inner Space in Flaubert and French Culture," Journal of Modern History $5^{1}$ (1979), 504-24. Mitzman sees pure art as a "sublimation" of the carnivalesque. But he thereby obscures the tensions between the two projects, and he furnishes little analysis of their relation to the functioning of Flaubert's novels. One may note, however, that pure art is perceived by Mitzman as a "protest of withdrawal" in a sense that attributes a critical function to the very turn toward formalism and the rejection of existing society. From Sartre's perspective (which Mitzman does not discuss), this putative act of aesthetic resistance is of course tantamount to escape and aggravation of nega- 


\section{Madame Bovary on Trial}

project has an uneasy, indeed agonistic, relation to that of pure art, although the two may at times establish unexpected connections with one another. But the carnivalesque cannot simply be subordinated to the quest for pure art in Sartre's sense of a derealization of the real and a flight into the imaginary. Nor can it be reduced to double binds that postulate bourgeois stupidity only to convert it through impotent laughter into merely demoralizing buffoonery. For this possibility is only the extremely negative end of a spectrum of carnivalesque effects that, while specific in nature, have a significant critical function and a crucial part to play in any larger project of sociocultural transformation. Indeed one way in which the project of carnivalization entered Flaubert's novels was through a many-sided contestation of the ideal of pure art itself. And a more prominent and lively role for carnivalizing forces may be seen not merely as a means but as part of the end of social action in its broadest sense.

Evidence for a carnivalesque project can be adduced from Flaubert's letters and from their bearing upon Flaubert's biography. The first known essay in prose that Flaubert wrote was an éloge of Corneille followed by an éloge of constipation. ${ }^{14}$ Jean Bruneau, in his study of the early works of Flaubert, has stressed the role of relatively unmediated carnivalesque elements. ${ }^{15}$ Yuk in Smarh was, for example, an ambivalent god of laughter. And of himself Flaubert wrote: "Whatever one may say, at

tive forces in society and culture. Mitzman also makes the suggestive remark that "one may view Madame Bovary as an extended metaphoric charivari against bourgeois marriage" $(521)$. My own general view is that the ideal of pure art can itself be seen as a "sublimation" of the carnivalesque largely in the paradoxical sense that something may turn into its opposite. The artist turned his back on society in quasi-ritualistic impudence. But he also sought an ideal of purity or transcendence and engaged in a quest for the absolute. The carnivalesque contests this very ideal through what Bakhtin calls "jolly relativity," and it is necessarily a mode of interaction and "impurity." But the carnivalesque itself did appear in a more "sublimated" or muted form in Flaubert-notably on stylistic levels where carnivalization is related to the entire problem of the role of irony and shifts in narrative perspective.

14. See Geneviève Bollème, Extraits de la correspondance ou préface à la vie d'écrivain (Paris: Editions du Seuil, 1963), 22.

15. Les Débuts littéraires de Gustave Flaubert (Paris: Armand Colin, 1962), 150-6o. Bruneau's study should be read as a companion piece to, and a check upon, Sartre's interpretation in L'Idiot de la famille. 
bottom I am a showman [or mountebank-saltimbanque]. In my childhood and youth, I had a boundless love of the stage. I would perhaps have been a great actor if heaven had made me been born poor" (August 6 or 7,1876 ). The analogue of Yuk in the life of the young Flaubert and the outlet for his theatrical sense was Le Garçon, a ribald and self-critical personification of the spirit of laughter. In Le Garçon, laughter, irony, and parody were combined with unsettling effect. Le Garçon was a fictive creature invented by Flaubert and his friends for theatrical representations they would perform in the billiard room of the Flaubert residence, the Hôtel Dieu. Le Garçon would assume the role of bourgeois, but he would carry that role to satirically hyperbolic extremes that would explode it convulsively from within. As Jean Bruneau puts it: "[Le Garçon] represents simultaneously the bourgeois at the time of Louis Philippe [le bourgeois louis-philippard] and the farceur who makes fun of the bourgeois. In and through him, Flaubert and his friends could satisfy both their idealistic aspirations and their pointed sense of satire and farce." ${ }^{16}$ Le Garçon was a kind of roundhouse, Rabelaisian Robert Macaire from whom the performer, as a part of his role, would take a (self-)critical distance. In the words of Flaubert's niece, Caroline, the Garçon "was a sort of modern Gargantua, of Homeric exploits, in the skin of a travelling salesman. The Garçon had a peculiar, noisy laugh which was a sort of rallying cry among initiates." 17 While the Garçon was not a purely nihilistic figure, he did have a sinister and even quasi-nihilistic side which lends partial support to Sartre's interpretation of his role. ${ }^{18}$ His laughter could be hysterically shrill, and his excavation of the bourgeois could go beyond the limits of this social role to undermining faith in man. It might not be too far-fetched to see one analogue of Le Garçon in that carnival figure out of season, that image of death in Madame Bovary, the Blind Man. Yet, as Flaubert recognized, there was a perverted remnant of the Garçon in Homais, the deadly adversary of the Blind Man: "The ridiculous char-

16. Flaubert Correspondance (Paris: Gallimard, 1973), 852.

17. Quoted by Albert Thibaudet, Gustave Flaubert [1922] (Paris: Gallimard, 1935), 20.

18. L'Idiot de la famille II, passim. 
acter in my novel is a Voltairian, a materialist philosopher (like the Garçon!)" [December 31, 1856]. The linkage between the Garçon and Homais in this letter is somewhat suspect, however, since the letter is written to convince a Bonapartist editor (Edmond Pagnerre) of Flaubert's innocence of the charges levelled at him during the trial. Still the Garçon does live in Homais in the restricted but of ten uproarious form of unself-conscious self-parody. More generally, the Garçon might be described as a "double inscription" or dual rendition of bourgeois stupidity in the largest sense-one both trading in the object of scorn and subjecting it to grotesque ridicule.

Another interesting fact from Flaubert's youth is his attendance at Legrain's marionette theater at the fair of Rouenand one of his greatest pleasures as an adult was when Legrain publicly recognized him in the audience. Flaubert first saw the story of Saint Anthony in Legrain's marionette version of it. The more outlandish forms of the carnivalesque, transformed into a proliferating pageantry of beliefs, heresies, and temptations, may have been one element that shocked his friends, Maxime Du Camp and Louis Bouilhet, in the first and most unbridled version of The Temptation of Saint Anthony-a characteristic that did not entirely disappear from its more disciplined versions. And Bouvard and Pécuchet has aspects of marionette theater in the bizarre and sometimes slapstick spectacle of minimally characterized, stock figures who are differentiated by a plethora of fragile and disorienting surface distinctions. Bouvard and Pécuchet seem like a doubling of Le Garçon in a modernized form of puppet or shadow theater.

Flaubert's early letters are of ten written with a burlesque and scatalogical sense of excess that caused the expurgation of certain of them. His later letters do not abandon this mode altogether, but they do moderate it somewhat. A letter to Louis Bouilhet, written during the composition of Madame Bovary, is especially compelling in its use of a Rabelaisian style and orthography. It is dated the day after Christmas, $185^{2}$, and signed Flaubertus Bourgeoisphobus.

Par affinité d'esperits animaulx et secrète coniunction d'humeurs absconses, ie me suys treuvé estre ceste septmaine hal- 


\section{Flaubert's Projects: Pure Art and Carnivalization}

lebrené de mesme fascherie, a la teste aussy, au dedans, voyre; pour ce que toutes sortes grouillantes de papulles, acmyes, phurunques et carbons (allégories innombrables et métaphores incongrues, ie veux dire) tousiours poussayent emmy mes phrases, contaminant par leur luxuriance intempestive, la nice contexture d'icelles; ou mieux, comme il advint à Lucius Cornelius Sylla, dictateur romain, des poulx et vermine qui issoyent de son derme a si grand foyson que quant et quant qu'il en escharbouylloit, plus en venoyt, et estoyt proprement comme ung pourceau et verrat leperoseux, tousiours engendrant corruption de soy-meme, et si en mourut finalement.

Through an affinity of animal spirits and a secret conjunction of hidden humors, this week I found myself to be exhausted by the same annoyances in the head and, indeed, internally as well; so that all sorts of swarming papulas, acnes, furuncles and carbuncles (I mean innumerable allegories and incongruous metaphors) grew up among my sentences, contaminating by their unseasonable luxuriance the latter's nice contexture; or better, as it bef ell Lucius Cornelius Sylla, the Roman dictator, by the effect of lice and vermin which issued from his skin in such a great plenty that, as soon as he squashed them, more would come, and he was like a proper porker and a leprous boar, always engendering corruption from himself, and in the end died of it. [This translation is intended only to give some sense of the meaning of the passage. It does not render Flaubert's astounding ability to capture Rabelais style and word-play.]

Mikhail Bakhtin, in his study of Rabelais, does not discuss the role of carnivalesque elements in Flaubert's novels or in more modern writers in general. He does indicate that modern literature is perhaps the privileged repository of modern carnivalesque tendencies which have nonetheless been reduced in force and form when compared with Renaissance manifestations, in part because of the separation of the modern carnivalesque from prominent public institutions such as carnival itself. Bakhtin's study of Dostoevsky nonetheless reveals the possibly revitalizing role of carnivalesque features in modern literature, and his work has helped to sensitize scholars to expressions of the carnivalesque in more out-of-the-way or relatively sub- 


\section{Madame Bovary on Trial}

merged aspects of modern culture.$^{19}$ Bakhtin himself provides a note on the early letters of Flaubert which is worth quoting:

An important role is usually played by the unpublicized spheres during the juvenile period of an author's development, when they prepare his creative originality (which is always related to a certain destruction of the prevailing world picture and to its revision at least in part). See, for instance, the role of these spheres of speech during the youth of Flaubert. In general, the letters of Flaubert and of his friends (during all periods of his life) offer rich material for the study of phenomena discussed here (familiar forms of speech, indecencies, friendly abuse, and aimless comic forms). See especially the letters of Poittevin to Flaubert and of Flaubert to Feydeau. ${ }^{20}$

Actually the appeals to the carnivalesque in Flaubert's letters go beyond the references indicated by Bakhtin, and they at times provide some insight into his novelistic practice. In excusing to Louise Colet his tendency to speak more of Shakespeare than of their relationship, Flaubert unguardedly declares: "I have tasted more than others the pleasures of the family, and as much as a man of my age the joys of the senses, more than many those of love; well none of these has given me bliss [jouissance] approaching that afforded me by a few illustrious dead whom I read, and whose works I contemplate" (October 3, $1846)$.

Those whose works he was reading and rereading during the composition of Madame Bovary included-aside from Shakespeare-Cervantes, Rabelais, Voltaire (notably Candide), Petronius, and Apuleius. We have seen how, in a letter of September $4,185^{2}$, he looked forward to the rebirth of books such as the Satyricon and The Golden Ass, Menippean satires informed by a carnivalesque spirit. And he defended the "lung power" of Hugo as a force that would give his work lasting value. He also

19. See, for example, Victor Turner, "Frame, Flow and Reflection: Ritual and Drama as Public Liminality" in Performance in Postmodern Culture, ed. Michel Benamou and Charles Caramello (Madison, Wis.: Coda Press, 1977), $33-55$.

20. Mikhail Bakhtin, Rabelais and His World, $422 \mathrm{n}$. 
tells us what he appreciates in Cervantes-not pure art as the "derealization" of the real but the interaction between the real and the imaginary: "What is prodigious in Don Quixote is the absence of art and that perpetual fusion of illusion and reality that make it such a comic and poetic book" (November 22, 1852). And he sounds a call for the renewal of the "robust outrages" of Rabelais:

I am furiously rereading Rabelais, and I feel as if I am reading him for the first time. He is the great fountain of French letters. Our strongest writers draw from him by the cupfull. We must return to his spirit-to robust outrages. Literature, like society, needs a curry-comb to fell the pests that devour it. In the midst of all the weaknesses of morality and spiritsince we all waver like exhausted people and there is in the atmosphere of our hearts a thick fog that prevents us from discerning straight lines-let us love the true with the enthusiasm one has for the fantastic and, in the measure that others lower themselves, we shall rise. [November 22, 1852]

The elitist tinge of this declaration is tempered by the feeling that all men share in a common lot. And while the dream was for Flaubert always the pinnacle of true art, the reading and rereading of the classics were not mere pretexts for day-dreaming in the sense of absenting oneself from reality. They were ways of keeping in touch with those works of quality and robust power Flaubert felt he could never equal but whose example would provide him with worthy objects of emulation in the face of temptations toward mediocrity. The directions in which Flaubert's artistic practice took this idea were quite different from those espoused by Matthew Arnold, but it is nonetheless important to note the similarity of concern motivating two exponents of "high culture" who are often seen as worlds apart. "Modernism" in Flaubert came bound up with a deep respect for the classics, a conviction that they alone merited intimate study, and a belief that modern art would have to seek different paths in part because it could not equal them. Their time had passed, and the difficulty was to take leave of them in the attempt to find a way in modern times to produce significant art. 


\section{Madame Bovary on Trial}

Leave-taking did not, however, imply the irrelevance of, or a total rupture with, the past. To some extent, the past might furnish an idea of what was missing but necessary in the present. In referring to figures of the past who might answer to needs of the present, Flaubert looked not for a Christ but for an Aristophanes of art:

Ah! What's missing in modern society is not a Christ, nor a Washington, nor a Socrates, nor even a Voltaire; it's an Aristophanes. But he would be stoned by the public. And then what's the use of all that, always to reason and to blab. Let us paint, paint without making up theories, without concerning ourselves with the composition of colors or with the dimension of our canvases, or with the duration of our works. [December 16 or $17,185^{2}$ ]

Yet, of course, Flaubert did attempt to theorize in his letters, and his theorizing at times departed from the ideal of pure art. Flaubert was, however, aware of the muted or toned-down nature of the carnivalesque elements in his own work, and this recognition blended with the feeling that he could not attain the heights of past masters. "My readings of Rabelais mix with my social bile and there forms a need for flow $[f l u x]$ to which I can give no outlet and which even bothers me, for my Bovary is tied with a cord-laced, corseted, and strung to the point of strangulation" (January 29-30, 1853).

It is significant that the need for "flow" is seen as coming from a mixture of "social bile" and the reading of Rabelais, thereby intimating the socially critical potential of the carnivalesque in modern life. In a letter five years earlier, Flaubert put the point in a more personal way:

For me the sad grotesque has an unheard-of charm. It corresponds to the intimate needs of my buffoonishly bitter nature. It does not make me laugh but dream at length [rêver longuement]. I take hold of it wherever it is to be found, and I, like everyone, carry it in me: that's why I love to analyze myself. It's a form of study that amuses me. What prevents me from taking myself seriously, although I have a rather grave spirit, is that I find myself very ridiculous-not with that relative ridiculousness which is the theatrical comic but with that ri- 
diculousness intrinsic to human life itself and that springs from the simplest action or from the most ordinary gesture. For example, never do I shave without laughing, so stupid [bête] does it seem to me. All that is very difficult to explain and must be felt. [August 21-22, 1846]

The notorious comment about shaving might be interpreted in Sartrean fashion as evidence of Flaubert's tendency to detach actions from goals that give them purposive meaning and thereby to dehumanize them. But this interpretation, while not altogether off the mark, is extremely limited. It is important that Flaubert's comment comes in the context of the muted carnivalesque where ordinary human activities become intrinsically ridiculous or sadly grotesque when they are seen differently or experienced as laughably stupid in a noninvidious comic spirit. This spirit need not be understood solely as evidence of neurosis, pathological passivity, or "pithiatism." It is to some significant extent a specific variant of the comic having distinctive affinities with automatic gestures that become strange once they are deautomatized-a view put forth by Henri Bergson and the Russian formalists (among others). As Albert Thibaudet writes in this regard:

Life appears comic to Flaubert only because he sees it immediately under the aspect of automatism. Shaving is stupid and comic only because it is a daily, mechanical action. But he knows it, while everything that is exactly foreseeable in the human individual becomes comic to the extent that he who says or does it is ignorant of the fact that it is foreseen. The Dictionary of Received Ideas, elaborated by Flaubert with so much joy, is the dictionary of clichés that a bourgeois would necessarily put forth in given situations. Madame Bovary like Don Quixote consists in incorporating this automatism of life in a work of art. Emma Bovary or Homais, Don Quixote or Sancho, are just that: the grotesque or the sad ridiculousness which makes one dream, which makes one think. ${ }^{21}$

The "aesthetic" perception of a simple act like that of shaving brings together an ordinary or "symptomatic" activity and 


\section{Madame Bovary on Trial}

one that may take on uncanny dimensions that are grotesque enough to induce dream. It is this peculiar intersection of the ordinary and the disconcerting that is especially troublesome in the art of Flaubert, for it points to the possibilities and limits of criticism and to the manner in which the pure opposition between practical action and receptivity does not cover all significant problems. This certainly does not emasculate criticism, but it does pose a barrier to a view that would found itself on unproblematic oppositions and the apocalyptic hope for total transformation of the given. For, on the most banal level of daily demands, the act of letting one's beard grow might appear as sadly grotesque as that of shaving it off, particularly in certain contexts.

It may be remarked that in one of his fullest plans for the preface to his Dictionary of Received Ideas, Flaubert described it in strikingly carnivalesque terms:

Have you noticed that I'm becoming a moralist? Is it a sign of old age? But I am certainly turning toward high comedy. Sometimes I have an itch to lash out at my fellow humans, and some day I will, ten years from now, in a long novel with wide range. Meanwhile an old idea has come back to me-that of my Dictionary of Received Ideas (do you know what it is?). The preface, especially, greatly excites me, and in the way I conceive it (it would be a book in itself) no law could touch me although I would attack everything. It would be the historical glorification of everything generally approved. I would demonstrate that majorities have always been right, minorities always wrong. I would immolate the great men on the altars of fools, deliver the martyrs to the executioners-and that in a style pushed to the extreme, with all possible fireworks. For example, I would show that in literature, mediocrity, being within the reach of everyone, is alone legitimate, and that consequently every kind of originality must be denounced as dangerous, ridiculous, etc. I would declare that this apologia for human vulgarity in all its aspects-and it would be raucous and ironic from beginning to end, full of quotations, proofs (which would prove the opposite), frightening texts (easily found) - was aimed at doing away, once and for all, with all eccentricities, whatever they might be. That would 
lead to the modern democratic idea of equality, using Fourier's remark that "great men won't be needed"; and it is for this purpose, I would say, that the book is written. It would include, in alphabetical order and covering all possible subjects, "everything one should say if one is to be considered a decent and likeable member of society"....

I think that as a whole it would deliver a strong punch. There would not be a single word invented by me in the book. If properly done, anyone who read it would never dare open his mouth again, for fear of spontaneously uttering one of its pronouncements. Furthermore, certain items could be gone into in quite splendid detail, for example, MAN, WOMAN, FRIEND, POLITICS, MORES, JUDGE. And a concisely written list of types could be included, to show not only what one could say, but what one should seem to be. [December 16 or 17 , $\left.185^{1}\right]$

The Dictionary of Received Ideas that Flaubert finally produced is a heteroclite amalgam of definitions not all of which are wrong or totally inept but all of which are-or are suited for conventional acceptance as-commonplaces. The Dictionary was to be supplemented by a sottisier in which Flaubert gathered quotations he hoped to make familiar from writers who were taken as authorities in various fields. The sottisier was dedicated not to the truly great, although even they might be caught napping, but to those accepted as great at a given time-the demi-nantis of the spirit who serve as guides to a larger public. Their pronouncements had the stupid or self-cancelling dormitive virtues characteristic of the authors consulted by Bouvard and Pécuchet in their mock-heroic quest for absolute knowledge and phronesis (practical wisdom). The Dictionary and the sottisier may have been intended as the compendium of raw materials that Bouvard and Pécuchet, after the failure of their attempt to live the messages conveyed in them, were to end their days copying - in a return to their origins or a grotesque creation myth that is an apparent reflection on the activity of their "creator." Indeed both the Dictionary and the sottisier raise the question of the relations among cliché, stupidity, the carnivalesque, and art in Flaubert himself.

The problem of cliché and its relation to stupidity represents 
one area in which the projects of pure art and carnivalization intersect in a manner having significant implications for Flaubert's actual practice in writing. The cliché or idée reçue is a social definition of reality that may attain the status of a secularized ritual object. Communication in the form of an exchange of clichés is a mainstay of collective life essential to civility and perhaps to social solidarity. Indeed the cliché is a limiting case of the problem of language use in general, for it raises the question of the relation between the given or the traditional and its critical reworking. And it may evoke more uncanny situations wherein the rapport between tradition and criticism becomes difficult to decipher.

When clichés are hollow or devoid of meaning, conversation that trades in them epitomizes the banality and stupidity of everyday life. Yet when the cliché is a sacred formula, its use may be rare and awe-inspiring; it is reserved for the supremely special moments in the rhythm of social life. The totemic emblem as described by Emile Durkheim might be seen as a hallowed cliché in this sense:

That an emblem is useful as a rallying-center for any sort of group is superfluous to point out. By expressing the social unity in a material form, it makes this more obvious to all, and for that very reason the use of emblematic symbols must have spread quickly once thought of. But more than that, this idea should spontaneously arise out of the conditions of common life; for the emblem is not merely a convenient process for clarif ying the sentiment society has of itself; it also serves to create this sentiment; it is one of its constituent elements.

In fact, if left to themselves, individual consciousnesses are closed to each other; they can communicate only by means of signs which express their internal states. If the communication established between them is to become a real communion, that is to say, a fusion of all particular sentiments into one common sentiment, the signs expressing them must themselves be fused into one simple and unique resultant. It is the appearance of this that informs individuals that they are in harmony and makes them conscious of their moral unity. It is by uttering the same cry, pronouncing the same word, or 


\section{Flaubert's Projects: Pure Art and Carnivalization}

performing the same gesture in regard to the same object that they become and feel themselves to be in unison. ${ }^{22}$

When a society is faced with a manque de base théologique, the hallowed becomes hollow, and cliché is converted into the code words or common currency of mass communication. Then the question is whether cliché itself provides some oblique mode of access to the sacred, perhaps through the narrow gate of stupidity. Insofar as language is crystallized into secular set pieces, the writer must come to terms with it. The obvious but potentially staggering problem is how to do so. In Flaubert, the cliché emblematizes the more general problem of writing as a mode of "double inscription" involving variable forms of proximity and distance in relation to the given. Proximity required the use of the given, perhaps empathy with it. Distance could be achieved through mention of the given, notably in ironic and parodic registers. Through complex modulations of proximity and distance that remain to be investigated, Flaubert could process or recycle the clichés of ordinary discourse and of literary writing.

The type of cliché from which Flaubert as narrator and as writer tried to take maximal distance was that of ordinary bourgeois stupidity. When this sort of cliché is employed in "objective" narration in Madame Bovary, it is of ten (but not invariably) italicized. The italic functions as an apparent alienation-effect to show that the narrator is not simply using the word or expression in his own voice but rather citing from another source. (As Stephen Ullmann remarks: "Italics play here the same role on the written page as intonation would in the spoken language, and we have . . . noted the close connection between intonation and the free indirect style.") ${ }^{23}$ When the cliché appears in the mouth of a character, it may be set in a direct quotation for which the narrator as objective reporter has even less responsibility. It is noteworthy that Homais is never presented "from the inside" but only through objective

22. The Elementary Forms of the Religious Life [1912] (New York: Free Press of Glencoe, 1965), 262.

23. Style in the French Novel (New York: Barnes \& Noble, 1964), 109. 


\section{Madame Bovary on Trial}

description, quotation of dialogue, and rare free indirect style where the ironic effects are rather blatant. In an earlier version of the novel, Flaubert considered concluding with an "insider's" portrait of Homais, but he tellingly decided to exclude it. In the version he published, the narrator's relation to Homais approaches the extreme of total ironic distance.

Yet distance can never be "total" enough, and there is always some taint of complicity or contamination when the narrator transmits the words or reactions of another-notably in the form of free indirect style. And it is always possible-given the strength of stupidity itself-that irony or parody will be misread and simply taken straight. Even Homais could conceivably be taken seriously as a model in life. Indeed, while Homais is never treated empathetically, there are signs that the relation of the narrator to him involves elements of self-parody and self-directed irony. Homais is, after all, more intelligent in his technocratic and pompous way than those around him. He is, moreover, the only writer in the novel. After the First Sentimental Education, Flaubert never directly presented an alter ego in the person of a writer as character in quest of pure art, perhaps because that fragile ideal would, in its fully exposed incarnation, be excessively open to the test of irony. But insofar as Madame Bovary is in some indirect and residual manner a Kunstlerroman, it is in part because of Homais. Indeed the partially self-parodic and ironic analogues of pure art in the novel are multiple. And Homais' technical, inflated use of language divorced from the utilitarian or pragmatic needs of everyday life itself bears some analogy to the role of language in pure art.

In fact, one quixotic path to pure art or the book about nothing would be the book composed entirely of clichés cut off from referents in reality and ironically distanced from the "voice" or views of the author. Here irony would be at its nihilistic and transcendental extreme in giving the author (narrator?) the position of a hidden God playing a cosmic joke on characters and readers alike. He would simply gather from social life or from books bouquets of petrified stupidity and report them with detached impassivity, thus giving the reader no clue as to how to react to them. This dream did entice Flaubert, and he approached it at times in a work such as 
Bouvard and Pécuchet. But even in that limiting experiment, the two cloportes acquire absurdly endearing qualities, and their achievement of the ability to recognize stupidity while no longer tolerating it is but one indication of their complicity with their "creator."

Thus maximal distance through ironic and parodic effects is sought in relation to the clichés of bourgeois stupidity, even though the quest-in some sense identical with the quest for pure art itself-is an impossible one. And one must recall that bourgeois stupidity covers a great deal of territory in Flaubert, including the discourses of political power, conventional religion, family life, and seduction. (It is almost like an oil slick that coats everything in its path.) Narrative distance is also marked but perhaps less extreme with reference to the clichés of romantic love. Indeed two analogues of the quest for pure art as an impossible absolute are Emma Bovary's quest for romantic bliss and Charles's idolatry of Emma. Emma's quest is hopelessly compromised (but perhaps not totally annihilated) by the vulgarity of the objects that are imbued with her imaginings. But Charles's devotion to Emma, especially after he discovers the love letters from Léon and Rodolphe which divorce his ideal of Emma as fully as possible from reality, is a "purer" form of dedication bearing the closest of resemblances to Flaubert's own paradoxical dream. To say this, however, is also to imply that the dream of purity or the quest for an absolute is always threatened by ironic deflation. The nature of that irony in its relation to pathos and empathy is the variable issue.

For irony in Flaubert is not always of a nihilistic or transcendentally distanced variety - and it can in any case only approximate that extreme. As Flaubert himself put it: "Irony takes nothing from the pathetic; on the contrary it increases it" (October $\left.9,185^{2}\right)$. Contemporary views of irony which, it is true, owe a great deal to Flaubert, at times stress its negative and equivocally self-serving sides. But in Flaubert there are essential modulations of irony bound up with pathos and empathy, and they serve to cast an uncommon light on certain forms of stupidity.

Flaubert's most hostile and negative irony is clearly directed against complacent bourgeois stupidity, although even here the 


\section{Madame Bovary on Trial}

author-narrator-writer is not free of all complicity in the object of scorn. The bourgeois not only traded in cliché; he believed he was actually saying something meaningful in "communicating" or communing in the hollow ritual of exchanging received ideas. The Comices agricoles or agricultural fair scene in Madame Bovary is a telling instance of Flaubert's treatment of clichés that are the mainstay of stereotypical modes of discourse. The clichés of romantic love (Emma's), of manipulative seduction (Rodolphe's), and of flatulently seductive political rhetoric (the speakers' at the fair) are not only cited; they are actively set against one another in a self-destructive crossfire or potlatch through which the language of cliché is reduced through static interference to noise and ultimately to empty silence.

There are, however, other modes of stupidity and cliché in Flaubert, and they have a different kind of relation to irony, for irony does manage to increase their pathos. And silence or inarticulateness itself may take on more positive qualities in the process. Stupidity here exists both below and above the commonplace plateau of bourgeois complacency-and there is an important sense in which the two manifestations of marginality meet in Flaubert's art. Indeed, in a rather subtle fashion, the very understanding of great art in Flaubert aligns it with the position of the oppressed or victimized.

Beneath ordinary bourgeois stupidity is the plight of the inarticulate victim or, more generally, the person at a loss for words who may be pathetic or ridiculous but who is also aweinspiring and worthy of respect. Here the irony of the narrator is not absent; but it has a function not identifiable with subjective transcendence or infinitely narcissistic play. Rather irony heightens pathos as very mixed feelings are evoked.

To some extent, Charles Bovary and Catherine Leroux in Madame Bovary may be seen in this light. But perhaps the most striking example is to be found in Un Coeur simple. This story is based on a skillful inversion of the normal expectations concerning the way irony functions. Normally, the first sense or reading is supposed to be literal or straight and the second, ironic. In the standard formulation of the nature of ironic statement, one says one thing and means another. In Un Coeur simple, the first or obvious meaning is ironic. For irony is bla- 


\section{Flaubert's Projects: Pure Art and Carnivalization}

tantly on the surface in the story of Félicité, the old servant who, after multiple disappointments, has her dead parrot stuffed and fetishistically worships it, identifying the dilapidated bird with the paraclete and in some sense sacralizing the death of language as the parrot-talk of cliché. Yet the arresting turn in the story is its ability to supplement inexpungeable irony with genuine pathos and feeling. Félicité emerges as a truly moving figure who leaves the reader with feelings he or she would prefer to leave mixed. Indeed Flaubert himself went so far as to assert that his "récit d'une vie obscure" was "in no way ironic as you may suppose, but on the contrary very serious and very sad" (June 19,1876$){ }^{24}$

The penultimate scene in A Sentimental Education involves, I think, similar processes. As Frédéric returns to meet an aging Madame Arnoux, his clichéd words of love are a memorial to the past that seem entirely divorced from their contemporary setting or real "referents." They are like secular ritual objects having no practical meaning-verbal blazons unhitched from reality. ${ }^{25}$ Yet this impression is not the only one conveyed in the passage. The entire meeting is permeated by the suspicion that Madame Arnoux, the "fetishized" object of Frédéric's fixation, has finally come to offer herself to him and thus to fall from the pedestal of purity that elevated her above a society of gen-

24. Philip Spencer writes: "It is as though Flaubert, after his personal trials, had transcended the harsh conception of Bouvard and Pécuchet and granted that a humble life of sacrifice and duty, however innocent of critical intelligence, possessed an intrinsic beauty and therefore an intrinsic meaning. To describe the accident that befell Félicité on the Honfleur road, Flaubert harked back, as Gérard-Gailly has shown, to the first incident of his illness outside BourgAchard [the fit at Pont l'Evêque]. The procedure is important, for it involves a parallel between Flaubert and Félicité, if not some degree of identification, and implies that if he could discover a pathetic but significant beauty in the life of the old servant, he also accepted the significance of his own suffering. It is a hint rather than an indication-a hint that Flaubert was not confining value to art but extending it to life, which for so long had seemed a "foolish joke." The accident outside Bourg-Achard and the years of tormented sensitivity from which there was no escape might after all have an unsuspected worth; and Flaubert was hovering on the brink of that exacting and courageous belief." Flaubert (London: Faber \& Faber, 1951), 222-23.

25. This interpretation is cogently developed by Jonathan Culler, Flaubert: The Uses of Uncertainty (Ithaca: Cornell University Press, 1974), 224-28. Culler's interpretation of cliché, irony, and stupidity in Flaubert may in general be compared and contrasted with the one I put forth. 
eralized prostitution and profanation. Yet Frédéric's own motives for shying away from physical intimacy are equivocal: he wants to preserve his ideal if only in memory; the encounter broaches both incest and imprudence; and the proferred object is now old and ugly. (Frédéric lights a cigarette to avoid what Rodolphe in Madame Bovary negates as he, a cigar between his teeth, mends with a knife the broken bridle of a horse.) The glimmer of light that reveals Madame Arnoux's gray hair is an intrusion of "reality" into the scene which Frédéric receives as if it were a blow in the chest. But the fact that these threats of "rude awakening" do not entirely destroy the poignancy of their meeting indicates that the mingling of memory, sentiment, reality, and cliché engages an interchange of irony and pathos that may gain in force from its very lack of "purity"including the purity of negative transcendence.

There are scenes in Madame Bovary that approach these high points of pathos and irony-one of them being the final encounter between Charles and Rodolphe. These scenes in general approach the nodal point at which art is not entirely exhausted by the categories of the symptomatic and the criticalthe point at which it evokes possibilities that would have a place in any social setting-but a place whose broader significance would certainly vary with the quality of that larger setting. At this point art itself broaches a "higher" form of stupidity and even a secular analogue of the sacred. This is the stupidity of the masterpiece that is ultimately-or perhaps recurrentlybeyond interpretation in the way it approaches the inarticulateness or silence of both nature and the speechless victim. But it may do this in a manner that does not simply revoke the power of criticism and that may even relate it to the more comprehensive possibilities of carnivalization-possibilities which touch upon fundamental forms of ambivalence that cannot be identified with ordinary equivocation or perceived in a spirit of invidious distinction, for they always bear upon the "self" as well as upon the "other." Indeed the very quest for le mot juste in Flaubert is itself a search for a higher-order cliché-one that goes beyond conventional cliché in finding that sacred and perhaps mythological turn of phrase that seems just right or irreplaceable. But the comprehensive function of art as a "higher" 
stupidity was formulated in more general and powerful terms by Flaubert himself-terms, of course, that do not entirely transcend cliché:

What seems to me the highest thing in art (and the most difficult) is not to evoke laughter or tears, or lust or anger, but to work as nature does: that is to say, to induce reverie [faire rêver]. And the most beautiful works have in fact this quality. They are of severe aspect and incomprehensible. As for their technique, they are immobile like cliffs, stormy like the ocean, full of foliage, greenery and murmurs like woods, sad like the desert, blue like the sky. Homer, Rabelais, Michelangelo, Shakespeare, Goethe seem to me inexorable. Such works are unfathomable, infinite, multifarious. Through little gaps one glimpses precipices; there is a darkness below, dizziness. [August 23, 1853] 